\title{
Human and Animal Individuals in the Middle Magdalenian
}

\section{Clément Birouste ${ }^{1}$}

Published online: 30 June 2020

(C) Springer Science+Business Media, LLC, part of Springer Nature 2020

\begin{abstract}
The category of "animal species" is at the heart of traditional interpretations of Palaeolithic art. In this context, animal depictions have traditionally been conceptualized in terms of the "animal species" they are supposed to represent. Moreover, the relationships between humans and animals have been discussed in similar terms. In this paper, I examine some innovative ways in which this relationship can be considered. In particular, I explore the possibility of interpreting animal images as representations of individuals, rather than just of species. Focusing on a number of pieces of rock art and portable images, and examining other kinds of activities (animal butchery, body adornment, treatment of human corpses, etc.) from the Middle Magdalenian (19,00016,000 cal BP), I seek to demonstrate how the concept of the "individual" offers a number of interpretive possibilities beyond the traditional category of "species". I argue that the focus on the head and face can reflect this interest in individualized animals. I also highlight the existence of practical techniques employed to create a relationship between human and animal individuals.
\end{abstract}

Keywords Magdalenian $\cdot$ Individuals $\cdot$ Species $\cdot$ Animals $\cdot$ Bones $\cdot$ Depictions

\section{Introduction}

Studying prehistory necessarily implies questioning the relationship between humans and (other) animals. The field of prehistory itself first developed around questions concerning the contemporaneity-which was not immediately clear to scientists - of human cultures and certain extinct animal species. In the early nineteenth century, when palaeontology first considered the existence of mammoths, woolly rhinoceroses, and cave bears in Western Europe, it was generally with the idea that it involved an

Clément Birouste

clement.birouste@univ-tlse2.fr

1 Université Toulouse Jean Jaurès, UMR TRACES 5608, Maison de la Recherche, 5, Allées Antonio Machado, 31058 Toulouse Cedex 9, France 
extinct fauna that had existed at a strictly separate time period from modern-day humanity and our current animal species, due to universal catastrophes. ${ }^{1}$ During the 1860 s, undeniable evidence gradually built up of the coexistence of humans and these extinct species (Richard 1992; Groenen 1994; Coye 1997), both thanks to the discovery of cut marks on the bones of extinct species, which appeared to have been made by human tools for food and technical purposes (Lartet 1860), and the discovery of depictions of extinct animals, often engraved on the bones of precisely these animal species (Lartet and Christy 1864). This discovery of varying kinds of concrete relationships between humans and certain animal species irrevocably proved the existence of an unprecedented era in humanity: prehistory.

It is following on from these questions regarding the many different aspects of the relationship between humans and animals that I propose this article, which considers this relationship from a global perspective and could allow us to renew certain approaches in Palaeolithic archaeology. Rather than compartmentalizing studies by categories of remains, I propose here to consider the links that might exist between the fields of iconography and hunting and butchering activities, in the hope that new avenues may emerge to be explored, especially in the field of Palaeolithic graphic representations.

This article focuses on the Middle Magdalenian (19 to $16 \mathrm{ka}$ cal BP, according to Barshay-Szmidt et al. 2016), which is an archaeological culture emblematic of the nomadic hunter-gatherers of the late Palaeolithic. Compared with previous phases, it is well represented in terms of the number of sites and remains documented and involves better taphonomic conditions. The archaeological traces of the Middle Magdalenian are particularly concentrated in the geographical area of southwest France and northwest Spain. ${ }^{2}$ At the time, this region was a mosaic of different environments: the middle valleys of the Aquitaine (Dordogne, Vézère, etc.), the plains of the Languedoc, the mountains of the Pyrenees, the Massif Central and the Cantabrian range, the shores of the Mediterranean and the Atlantic, the sandy desert of the Landes, etc. During this period, the climate was essentially cold and dry (Heinrich 1) in this region (Langlais 2007).

From the very development of the discipline, right up to the present day, animal representations and animal skeletal elements found at archaeological sites have been the main resources available to archaeologists upon which to establish the relationships between humans and animals in the late Palaeolithic. Such representations are particularly numerous for the Middle Magdalenian at once in the rock art, body ornamentation, and bone and lithic portable art; and many specialized and more generalized studies have been carried out on the matter (Breuil 1952; Leroi-Gourhan 1965; Vialou 1986; Delporte 1990; Sauvet and Wlodarczyk 1995; Lorblanchet 2010; Airvaux 2001; Tosello 2003; Taborin 2004; Plassard 2005; Bégouën et al. 2009; Fritz 2010; Bourdier 2010 ; etc.). At the same time, high quantities of animal skeletal remains have been documented at Middle Magdalenian sites, and a large number of detailed studies have

\footnotetext{
${ }^{1}$ This was, for example, the position defended by Cuvier (1985, first ed. 1825), the most influential palaeontologist of the time.

${ }^{2}$ The definition of the Middle Magdalenian varies nevertheless between southwest France and northwest Spain: the French Early Middle Magdalenian is contemporary to the Cantabrian Lower Magdalenian and is not included in the Spanish definition of the Middle Magdalenian (González Sainz and Utrilla 2005).
} 
been carried out (Delpech 1989; Fontana 1999; Costamagno 1999; Laroulandie 2000; Kuntz et al. 2016; etc.).

The animal skeletal remains and animal representations are usually separated and interpreted in different ways by two different archaeological fields: zooarchaeology and the study of iconography. However, it seems to me that this division is a poor reflection of the interweaving of these two fields such as is observed in the remains from the Middle Magdalenian. This paper thus proposes a combined approach to the animal skeletal remains and animal representations.

Furthermore, the relationship between humans and animals is generally interpreted in Palaeolithic archaeology through distinctions between animal species. However, it seems that other information could also be conveyed by the remains attributed to the Middle Magdalenian, notably an individualization of both humans and animals.

The aim of this paper is thus to explore the possible tendency to individualize animals in the context of the Middle Magdalenian beyond classification by animal species, through an approach combining both animal representations and animal bones.

\section{Materials and Methods}

\section{Representations of Animals and Animal Bones in the Middle Magdalenian}

\section{Representations of Animals}

Animal representations are numerous in the Middle Magdalenian and dominate the category of figurative motifs, although it is the abstract and geometric figures that dominate the corpus of art as a whole when all the different categories are considered together (White 2003; Fritz 2010). This predominance of animal representations is observed at once in the rock art, ornamentation of tools, body adornments, and even engraved stone assemblages. Large ungulates are the most commonly represented (in particular, horse and bison), while carnivores, birds, and fish are rarer (Sauvet and Wlodarczyk 1995; Sauvet et al. 2012). Humans and composite creatures are generally only represented in small numbers (Sauvet and Wlodarczyk 1995). ${ }^{3}$ At the scale of a region or a site, the order of frequency of representation of these species can vary substantially however (Sauvet et al. 2012). Finally, some subjects are rare or absent from any depictions; that which we might call the "natural environment" (the vegetation, landscapes, clouds, mountains, etc.) is absent, and the details of human life (activities, tools, clothing, etc.) are also rare, especially in the rock art.

Middle Magdalenian rock art (engraved, painted, drawn, and carved) is considered to have a strong tendency toward realism (Breuil 1952; Leroi-Gourhan 1965; Fritz 2010; Bourdier 2010) characterized by the degree of completeness and detail of the depictions. The dynamism, degree of anatomical detail, forms, proportions, perspectives, and volumes have been carefully conveyed. A stylistic "naturalism" is often

\footnotetext{
${ }^{3}$ The percentages of different animal species depicted in Middle Magdalenian rock art can generally be considered through studies concerning the Upper Palaeolithic as a whole (Sauvet and Wlodarczyk 1995), since the vast majority of decorated Palaeolithic sites in the Franco-Cantabrian region have been attributed to the Middle Magdalenian. In some cases (Sauvet et al. 2012), two phases have been distinguished (before 14,500 BP and after 14,500 BP).
} 
evoked in this respect (Bégouën et al. 2009, p. 365; Fritz 2010, p. 218; Airvaux 2001, p. 25). This Middle Magdalenian rock art is also very often described as conforming to specific "codes" (Bégouën et al. 2009, p. 365), implying that it involves a combination of attention to detail and conventional reproduction (Bourdier 2010, p. 272).

For the Magdalenian, figurative art is also found in significant quantities on objects related to everyday life and this is one of the main characteristics of this chronocultural complex. There is no major disparity in the modes of representation in rock art and on other objects for the Middle Magdalenian: the predominance of animal figures and the tendency toward realism (associated with strong cultural conventions) are noteworthy in both forms of expression. ${ }^{4}$ The basis is clearly the same and, if there is a difference between rock art and portable art, it is probably more a question of function and place in everyday life. The category of "portable art" is nonetheless artificial, and the definition is vague due to the variety of existing expressions. Thus, portable art should ideally be discussed in terms of different subcategories and types of objects rather than as a single category (Averbouh and Feruglio 2012). We shall discuss different examples of objects decorated with animal figures in this article and describe the unique features of each of them.

\section{Animal Bones}

Animal skeletal elements are particularly numerous at sites attributed to the Middle Magdalenian, and bone remains from reindeer, horse, and large bovines have been documented at most sites. Reindeer remains predominate in the assemblages at residential camps in the Perigord, the Quercy, the Languedoc, and the Western Pyrenees (Fontana 1999; Costamagno 1999; Castel et al. 2007; Langlais et al. 2012; Costamagno et al. 2016). Horse and bovine remains also sometimes predominate (Langlais et al. 2012), while those of saiga antelope are particularly numerous in the Gironde and the Charente (Delpech 1989; Costamagno 1999). In the northern Pyrenean mountains, reindeer bone remains often predominate together with a relative diversity of other species, while in the southern Pyrenean mountains, hunting was more focused on deer and ibex (Costamagno and Mateos 2007).

A large proportion of these bone remains obviously came from animals that were hunted and consumed, and they often have cut marks demonstrating the very intense exploitation of the ungulate carcasses: skin removal, defleshing, disarticulation, tendon extraction, fracturing of bones to retrieve marrow and grease, etc. The treatment of these carcasses is very standardized, without any significant chronological or geographical variations (Costamagno et al. 2009; Soulier et al. 2014; Kuntz et al. 2016). It should be noted, however, that skulls were more frequently carried away from slaughter sites than certain other skeletal elements, which cannot be explained by economic or technical reasons (Kuntz et al. 2016). It has also been proposed that the care taken over the disarticulation phase observed in bone assemblages from the Magdalenian may imply a ritual context (Costamagno and David 2009; Kuntz et al. 2016). The

\footnotetext{
${ }^{4}$ The varying degrees of detail on the engraved stone plaquettes are nonetheless noteworthy (Tosello 2003; Bégouën and Clottes 1990). The thematic choices are a little more diverse in the portable art than in the rock art and include more small animals, such as insects and small mammals (Bégouën and Clottes 1990; Paillet 2014).
} 
meticulous disarticulation of all the limb bones does not seem attributable to any known technical reason. Nor can the practice be explained by a desire to share the carcasses between the different members of the group, as some of the disarticulated elements do not correspond to the fleshy parts of the animal and do not contain a medullary cavity. This disarticulation cannot be explained by the requirements of the bone marrow fracturing process either, since the small carpal and tarsal bones, which have been systematically separated from each other, do not contain any medullary cavity. On the other hand, this same practice has been observed among the Siberian Evenk (Abe 2005), for example, and in this context, the exhaustive disarticulation of the skeleton is a sign of respect for the animal handled.

The importance of animal skeletal elements (and carcasses) in the Magdalenian, beyond any strictly economic or nutritional purposes, is now widely accepted. Body ornamentation is often made up of bones and teeth which have been very little worked, and for which perforation is often the only sign that they were used as adornment (Taborin 2004). Furthermore, the voluntary depositing of bones has been repeatedly documented for the Middle Magdalenian, in various contexts, which seem impossible to explain by economic or technical reasons. Bones have often been found forcefully inserted into the cracks of decorated cave walls from the Middle Magdalenian (Bégouën and Clottes 1981; Peyroux 2012), for example, and entire animals have been brought into decorated caves, including ducks at La Garma (Arias et al. 2011; Ontanon and Arias 2012), a snake at Tuc d'Audoubert (Bégouën et al. 2009), and a salmon at Fontanet (Vialou 1986). The fossil bones of cave bears have been moved, modified, and removed at Tuc d'Audoubert (Bégouën et al. 2009), and a significant collection of horse mandibles has been intentionally compiled in a limited area at Abri Duruthy (Birouste et al. 2016; Birouste et al. 2018). For Magdalenian populations, animal bone remains were not therefore merely limited to "cooking waste".

\section{Correspondence Between Animal Bones and Representations}

A correspondence between animal bones and representations is common in the Middle Magdalenian. This can sometimes be observed in the form of intentional spatial connections between the bones and representations. At Abri Duruthy, for example, the collection of horse mandibles mentioned above was found in direct contact with the famous horse statuettes (Birouste et al. 2018). In addition, a meaningful relationship has sometimes been evoked between bones that have been forcefully inserted into cave walls and the iconography located in the direct vicinity. At the lower level of Tuc d'Audoubert, for example, a fragment of bison diaphysis has been forcefully inserted into the wall near a depiction of the same animal (Bégouën et al. 2009).

A correspondence between animal bones and representations is even more frequently observed in the modes of graphic expression that involve representations on bones or that incorporate bones into representations. Bone material was frequently used as a basis for carving or engraving graphic expressions (Delporte 1990; Taborin 2004; Cattelain and Bellier 2014; etc.). At the same time, animal representations are particularly common in engravings and sculptures, creating a link between animal themes and animal material. However, there is no guarantee that this connection was significant to Middle Magdalenian populations. The bone matter could have been chosen for its material qualities, without any specific reference to the animal it came from. On the 
other hand, the question of reference to the animal and its bones arises when we see the iconography presented on preserved and identifiable bone forms. A perfect match between theme and material is very characteristic of the portable bone art of the Middle Magdalenian (Tosello 2003; Aurière 2012). The artists frequently sought to set their depictions within the preexisting forms of the skeletal elements, for example, reflecting an undeniable interaction between the two elements. Pendants in the shape of animal silhouettes - the so-called contours découpés that are such characteristic body ornaments of the Middle Magdalenian in the Pyrenees - are a particularly good example of this interaction between theme and material. Among these depictions, which often involve an isolated part of an animal's body, representations of horse heads amount for more than three-quarters of the corpus attributed to the Middle Magdalenian (Cattelain and Bellier 2014). In most cases, these pendants have been created from barely modified horse stylohyoid bones (Delporte 1990; Cattelain and Bellier 2014) —a flat bone whose natural shape evokes the triangular profile of a horse's head (Delporte 1990) (Fig. 1). Moreover, $80 \%$ of the stylohyoid bones used as material for engraving or as ornaments during the Palaeolithic came from horses (Cattelain and Bellier 2014). The use of forms that are natural but known and recurrent - such as the shape of animal bones - can suggest a certain amount of intentional planning. All horses have a stylohyoid bone, and they always have approximately the same shape. This makes it possible to reproduce the same type of object while relying on a natural shape. In this, the repeated production of images on raw anatomical elements differs a little from the production of images on natural forms in general (lithic material, for example) which are much more random.

For the Middle Magdalenian, graphic representations of skeletal elements have sometimes been observed. At Mas d'Azil (Ariège), depictions of skinned horses' heads (collective 1996: MAN 47080; MAN 47340 + 4790; MAN 47026) reflect the artists' interest in the skeletal elements (Fig. 2). At the same site, engravings depicting contours découpés rather than depicting horses themselves (Fig. 3) have also been documented (collective 1996, p. 280, MAN 47076; Cattelain and Bellier 2014), reflecting a dialogue between bones and representations.

Finally, it is noteworthy that in the remains attributed to the Middle Magdalenian, references to the animal have been made both in the context of an iconic relationship (a representation that looks like a real or potentially real animal) and in the context of an

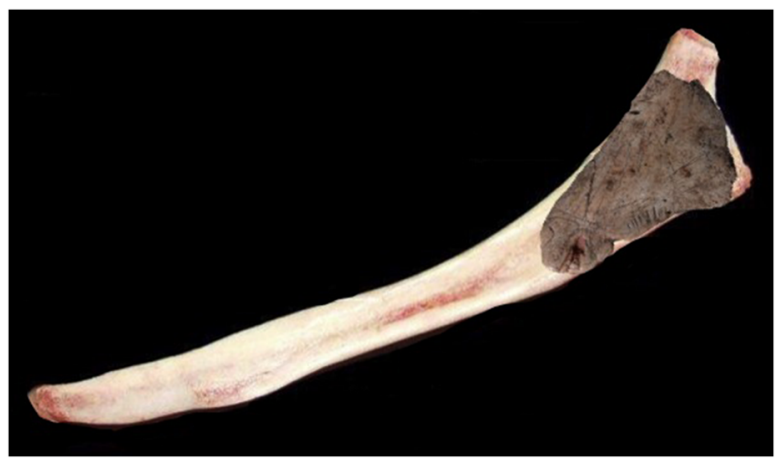

Fig. 1 Location of a "contour découpé” from the Cave of Enlène (@ Association Louis Bégouën) on a horse stylohyoid bone 


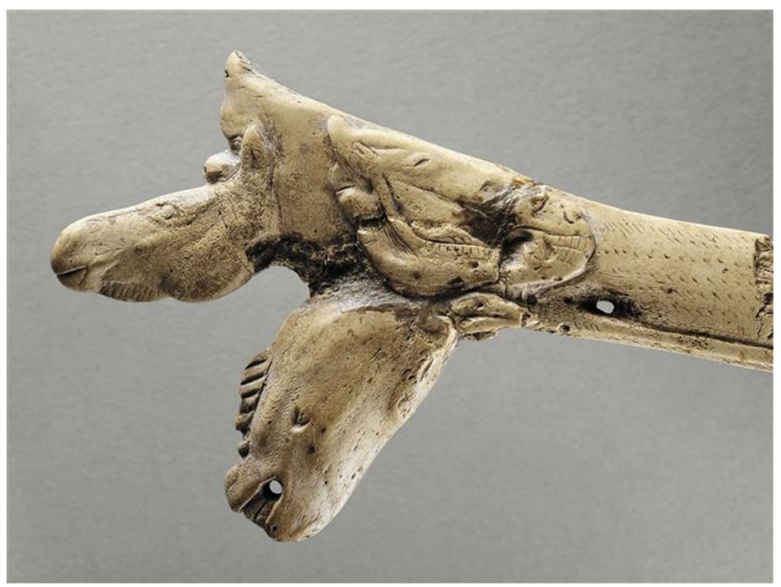

Fig. 2 Fragment of a spear thrower from the Cave of Mas-d'Azil. A skinned horse's head is carved in basrelief (MAN 47080, (C) RMN-Grand Palais, MAN/Martine Beck-Coppola)

indexical relationship (an element that actually comes from an animal), according to the terms defined by Peirce (Peirce 1960, first ed.1903). These references have in many cases been combined - by seemingly intentional arrangement (voluntary spatial proximity) or on the same object (certain depictions of animals on bone material). Animal bones and representations thus sometimes appear to have been equivalent signs for Middle Magdalenian populations. As such, the classic approach in Palaeolithic archaeology, which systematically separates bones and representations, creates a division in what appears to have been a continuity. This systematic division is probably derived from our modern system of thought and institutions, which often postulate the existence of a universal distinction between an economic and nutritional sphere on the one hand and a symbolic sphere on the other (Birouste 2018). This assumption is not, however, consistent with that which is observed in the Middle Magdalenian and could hence

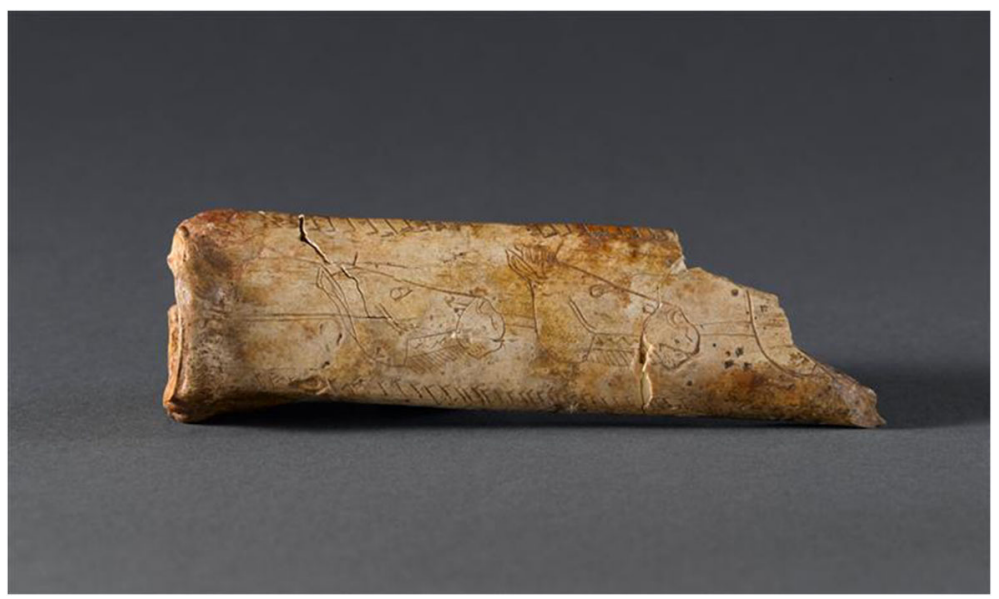

Fig. 3 "Contours découpés" depicted on the right metatarsal of a reindeer, from the Cave of Mas-d'Azil (MAN 47076, @ RMN-Grand Palais, MAN/Thierry Le Mage) 
obscure some overall characteristics that could be of interest to us. For this reason, this paper proposes an analysis combining different fields of Palaeolithic archaeology.

\section{Distinguishing Animals by Species}

In Palaeolithic archaeology, the question of the relationship between humans and (other) animals is classically addressed according to categories of animal species. These categories are obviously justifiable as a tool derived from biology. But this paper looks at the manner of perceiving and organizing the environment typically attributed to Palaeolithic communities, and we cannot be certain that these communities systematically used the same means of classifying animals as modern-day archaeologists.

Taxonomic division, systematics, and comparative anatomy are central tools in zooarchaeology, and a large part of the work consists in identifying the species present in archaeological assemblages, counting them, studying the differences in their treatment, and using them to reconstruct an environment and a chronology. The majority of the graphs and tables produced by zooarchaeologists therefore present results based on distinctions between animal species. While animal species are used here with the intention of objectifying nature, the fact remains that this vision may in some cases be an obstacle to perceiving the environment as it was viewed by past communities. The problem becomes even clearer when considering the study of Palaeolithic art directly based on the interpretation of symbols used by prehistoric groups. This is notably the case for studies referring to structuralism and semiotics, which generally take the species as a base unit. This structuralist approach to analysing rock art was influential in France in the 1960s with the work of Laming-Emperaire (1962) and Leroi-Gourhan $(1965)^{6}$. From this perspective, Palaeolithic rock art is considered to function like a text that must be deciphered by internal analysis. As such, the graphic productions are considered to be a visual language, composed of graphic signifiers and composition rules (Sauvet and Wlodarczyk 1995, p. 194). It is thus a matter of identifying structural standards in the arrangement of the graphic productions, by studying the combinations, associations, frequencies, absences, and spatial distributions involved. In the vast majority of structuralist and semiotic approaches to rock art, the animal species is the most elementary signifier. Leroi-Gourhan refers to this as the "signifying particle" (Leroi-Gourhan 1983, pp. 353-354). It is thus first and foremost the animal species that are quantified, and whose locations, combinations, and relative frequencies are studied. Furthermore, this approach is in perfect accordance with that of Lévi-Strauss when he states that "the diversity of species provides man with the most intuitive image at his disposal and is the most direct manifestation he can perceive of the ultimate discontinuity of reality. It is the perceptible expression of an objective coding" (Levi-Strauss 1990, p. 166, first ed. 1962). From this perspective, to the most advanced degree of interpretation, the aim is to match human symbols and animal

\footnotetext{
${ }^{5}$ The desire to understand the human-animal relationships of the Middle Magdalenian from a noncompartmentalized perspective also encourages us to question human/animal duality. This paper therefore examines both animal and human bones and representations of both animals and humans without presupposing their disjunction.

${ }^{6}$ While it is arguable whether Leroi-Gourhan can be assimilated under the general structuralist project put forward by Levi-Strauss in social anthropology, it nonetheless seems that his approach to Palaeolithic rock art adopted this perspective (Birouste 2018).
} 
series, by attempting to identify the signified element attached to the signifier. The history of the field shows that such results are always debatable however ${ }^{7}$ and possibly even unattainable (Sauvet and Wlodarczyk 1995). On the other hand, some structural recurrences based on animal species seem defensible and could confirm the importance of this category in zoological classifications for the Magdalenian. The animal species that are represented in caves are undeniably selected from a broad continuum of life, and their locations and associations may not be fortuitous (Laming-Emperaire 1962; Leroi-Gourhan 1965; Sauvet and Wlodarczyk 1995). However, there may have been a possible overinvestment in the structuralist method toward animal species. Indeed, with this approach, rock art depictions were typically classified by the sole criterion of animal species (Laming-Emperaire 1962; Leroi-Gourhan 1965; Sauvet and Wlodarczyk 1995), leaving aside the other information conveyed, which could be potentially significant: the number of figures per species; the sex of the animals; their posture, size, and orientation; the completeness of the depictions, and so forth.

Palaeolithic archaeologists can collect information about animal species (whether bone remains or iconography) relatively easily from remains that are particularly fragmented or damaged. They can thus establish the total number of each species in a given field: reindeer bones are very common among food remains, deer and its canines are often used for ornamentation, horses are the most frequently depicted animal, etc. However, this information cannot necessarily be considered significant from the point of view of the communities studied. It is not because archaeologists are able to determine the animal species involved that they can be sure of the emic categories involved. Reindeer were probably not strictly synonymous with "basis of economy", red deer with "useful material for ornamentation", and horse with "symbol". Furthermore, it is always possible that other categories than that of animal species were involved for the communities studied. An overly rigid classification, which only takes animal species into account in order to reconstruct the relationships between humans and animals, risks being reductionist and imprecise. This article therefore proposes considering other possibilities, in particular an exploration at the individual level, when examining Magdalenian remains.

\section{Human and Nonhuman Individuals Among Some Middle Magdalenian Remains}

This analysis proposes to test the tendency toward the individualization of beings for different categories of remains. This is not with the aim of replacing the species scale by another scale which would be considered the only signifier but rather of trying to bring a better definition to the bigger picture.

\section{Rock Art}

The rock art of the Middle Magdalenian is characterized by respect for the proportions, the detail of the muscular parts of the body, the precision of detail of the coat, and the

\footnotetext{
${ }^{7}$ The meaning of the symbols varies according to the interpretations: for Leroi-Gourhan (1965), horses are a masculine symbol and bison a feminine symbol. For Laming-Emperaire (1962), the opposite is true.
} 
degree of completeness of the animal figures (Breuil 1952; Leroi-Gourhan 1965; Bourdier 2010; Fritz 2010). These are all characteristics that effectively favour an initial identification of the animal species represented. Moreover, synoptic motifs, or motifs pertaining only to certain elements of an animal's body, sometimes seem limited to the identification of animal species alone (cervico-dorsal curves of mammoth or bison, isolated horse manes, etc.). The rock art attributed to the Middle Magdalenian is also defined by particularly marked conventions (Bégouën et al. 2009; Bourdier 2010). These conventions often refer to attributes that also favour the identification of species. In the case of bison, for example, the horn in the foreground is generally presented in the shape of an "S" and the horn in the background in the shape of a "C". This graphic construction "is so widespread that it is often sufficient to recognize a Magdalenian bison" (Bégouën et al. 2009, p. 367). The use of codes allowing the identification of animal species is therefore central to Middle Magdalenian rock art.

On the other hand, it should be noted that the mimetism observed in the representation of animals goes beyond mere reference to the category of species. In the vast majority of examples of Middle Magdalenian rock art, some details are related to the animal species, but others are related to the sex, age, season, posture, state of health of the animal, and so forth. This mimicry often results in the individualization of animals. The figures are not always stereotypes of horses, bison, or mammoths but in many cases involve unique individuals (Guthrie 1984). In the Cave of Altamira, it is possible to identify a strong male bison (bison 18), a female bison whose udder is clearly visible (bison 9), a young foal recognizable by the length of its neck and legs (horse 19), and so forth (Freeman and Gonzalez 2001). When a bison specialist observes bison represented in the rock art of the Ariège region, he sees individuals distinguished by the realism of the depictions: "a young female bison in a waiting posture" or "an old male bison in an attacking position", for example (Clottes et al. 1994). In the Cave of Rouffignac, a frieze shows three woolly rhinoceroses, each of which can be distinguished by certain figurative attributes: one of them appears younger because of the small size of its hump, another has a horn with an inverted curve, and the third has a broken horn (Plassard 1999) (Fig. 4). Numerous examples of the individualization of animals can be found in monographic studies of important decorated sites attributed to the Middle Magdalenian: Las Monedas (Ripoll 1972), Le Tuc d'Audoubert (Bégouën et al. 2009), Les Trois-Frères (Bégouën et al. 2014), Altamira (Freeman and Gonzalez 2001), Rouffignac (Barrière 1982; Plassard 1999), Niaux (Clottes 2010), Le Roc-auxSorciers (Iakovleva and Pinçon 1997), Altxerri (Altuna 1997), Ekain (Altuna 1997), Tito Bustillo (Balbín and Moure Romanillo 1981, Balbín and Moure Romanillo 1982) and Le Portel (Beltrán et al. 1966).

The different criteria that lead to this individualization of animals in the rock art of the Middle Magdalenian do not seem to involve a systematic coding that always follows the same strict process. In the Cave of Rouffignac, depictions of mammoths show varying amounts of detail depending on the context (Plassard 1999; Plassard 2005). The scope of these depictions ranges from "abbreviations" in which the species alone can be identified, to detailed figurations presenting specific individual features. It is interesting to note that the progression toward detail does not follow a cumulative sequence. Out of the 158 mammoths, $56 \%$ have one eye, $71 \%$ have tusks, $31 \%$ have one or more legs, and only 7 have all four legs (Plassard 1999). The author thus appears to have sought to depict a specific individual belonging to a particular species, rather 


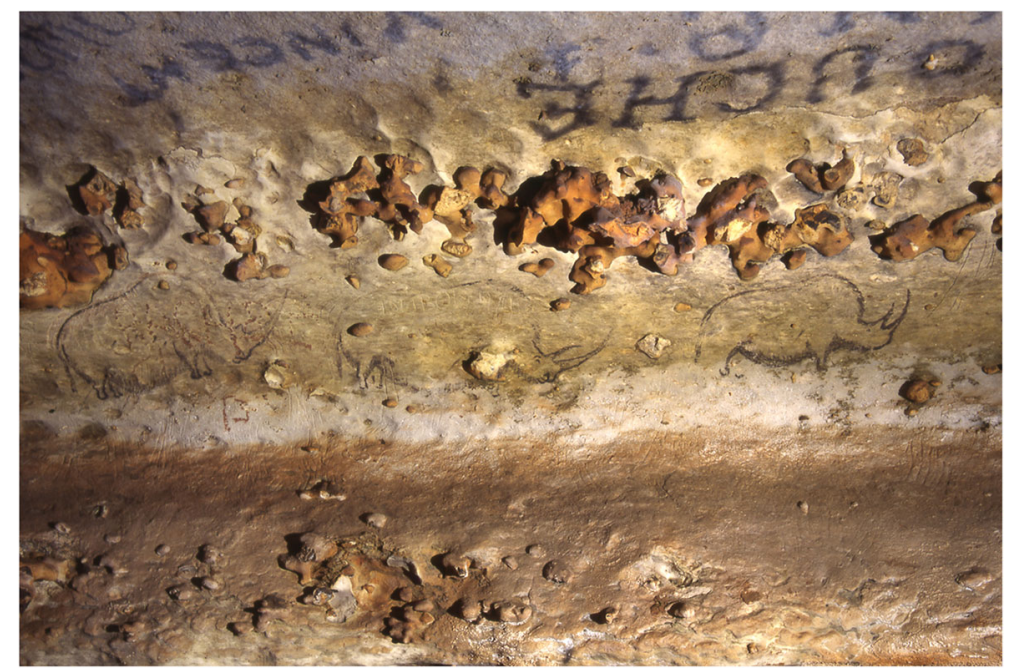

Fig. 4 In the Cave of Rouffignac, a frieze shows three woolly rhinoceroses, each of which can be distinguished by certain figurative attributes (@ J. Plassard)

than first trying to present the species itself through a stereotypical symbolic framework onto which they could then graft varying degrees of detail following a preestablished mental process. There does not seem to be any systematization in the representation of mammoths, even though they are all identifiable as such. It was thus perhaps a case not only of presenting mammoths but also of conveying the variety of different mammoths involved.

Finally, it is not a matter here of ascertaining the actual existence of each unique animal. It is possible that their individual features were based on animal models that actually existed, just as it is possible that there was a deliberate intention to depict an imagined, but realistic, individual animal by providing a large number of morphological details. This process is, moreover, common in Western iconography of humansin comic strips and advertising, for example, characters are made unique and recognizable without necessarily representing real people.

\section{The Engraved Stone Assemblages}

The Middle Magdalenian engraved stone assemblages involve significant quantities of material. Over a thousand pieces have been documented, for example, at the sites of Bédeilhac (Sauvet 2004), Enlène (Bégouën and Clottes 2007), and La Marche (Pales and Tassin de Saint-Péreuse 1989). The figurative themes involved in these collections of engraved stones are mainly based on animals (Sieveking 1987; Tosello 2003) and involve significant differences in animal percentages according to the geographical regions, notably with the remarkable frequency of humans in the region of Poitou (Fuentes 2015). The detail and quality of the iconography of these pieces varies greatly, ranging from simple sketches to highly detailed works (Tosello 2003; Bégouën and Clottes 1990; Bégouën et al. 2009). However, as with the rock art, the same realistic figurative tendencies allow us to identify and distinguish specific individuals in a number of cases. This individual scale has already been recognized and discussed with 
regard to the engraved plaquettes of the Magdalenian, insofar as they sometimes present realistic human figures, explicitly differentiated from each other by their individual attributes (beards, hairstyles, postures, etc.). This is the case for the engravings on the limestone platelets and slabs at the caves of La Marche in Vienne (Pales and Tassin de Saint-Péreuse 1976). Certain human depictions there could be likened to portraits (Saint-Mathurin 1973; Fuentes 2015), although it is not known whether these figures were actually of real individuals (Fig. 5). It equally appears that this individualization may go beyond humanity and also apply to animals. In the cave of La Marche, the animals, which have been depicted in greater numbers than humans, have also been presented in a "naturalistic" manner ${ }^{8}$ (Pales and Tassin de Saint-Péreuse 1981, 1989; Airvaux 2001; Mélard 2008). This mode of depiction favours the individualization of animals (Fig. 6), and the concept of a "portrait" could therefore be applicable to both humans and animals.

Most of the time for the engraved stones of the Perigord Magdalenian, only one animal has been depicted on each piece (Tosello 2003). With the portable art on the plaquettes from the caves of Volp (Ariège), there is also almost always only one subject per engraved side: there is only one exception to this among the 27 engraved sides from the Tuc d'Audoubert, and another possible one among the 82 engraved sides from Enlène that have been published (Bégouën and Clottes 1990). At Bédeilhac, in the vast majority of cases, each stone also corresponds to an animal figure and incorporates the shape of the stone into the depiction (Sauvet 2004). It can thus be concluded that the depictions on the engraved stones essentially draw a link between an individual animal and an object. ${ }^{10}$

\section{The Contours Découpés in the Shape of Horses' Heads}

The contours découpés discussed above are ornaments which most often involve the depiction of a horse's head on a horse stylohyoid bone (Cattelain and Bellier 2014). They are therefore easily recognizable pieces, which respect common graphical and morphological codes (Buisson et al. 1996). These contours découpés representing horses are paradoxically very unique pieces with respect to each other, and each object differs from the next in the major collections ${ }^{11}$ (Cattelain and Bellier 2014).

For the collection from Enlène (Bourdier and Birouste 2019), aside from a basic graphic framework - mouth, nostrils, eye, whiskers, and muzzle - the

\footnotetext{
${ }^{8}$ A variability in tendencies toward naturalism or schematism nevertheless exists in the Magdalenian, leading to a greater or lesser individualization of the subjects. These variations could reflect the existence of different cultural facies within the Magdalenian, and they concern humans (Fuentes et al. 2016) as well as other animals (Rivero and Sauvet 2014; Sauvet and Rivero 2016; Bourdier et al. 2016).

${ }^{9}$ While graphic conventions relating to the species represented could be more important for animals than for humans (Fuentes and Pinçon 2018), the concept of a "portrait" nevertheless seems to be applicable in both cases. Graphic conventions do not exclude singularizations, as shown, for example, by the famous "Fayum mummy portraits" (Walker 2000), which attest to important stylistic constraints but represent distinct individuals.

${ }^{10}$ This is a fortiori the case with regard to the statuettes, which are widespread in the Magdalenian.

${ }^{11}$ In the collections from Enlène, Isturitz, and Mas d'Azil, the horses can be distinguished from each other. The contours découpés at Labastide (Fritz and Simonnet 1996), on the other hand, show an unusual homogeneity. This homogeneity is often extrapolated to all objects of this type, despite the exceptional nature of the collection: their discovery as a group, and the recurrence of the ovicaprid theme and absence of horses.
} 


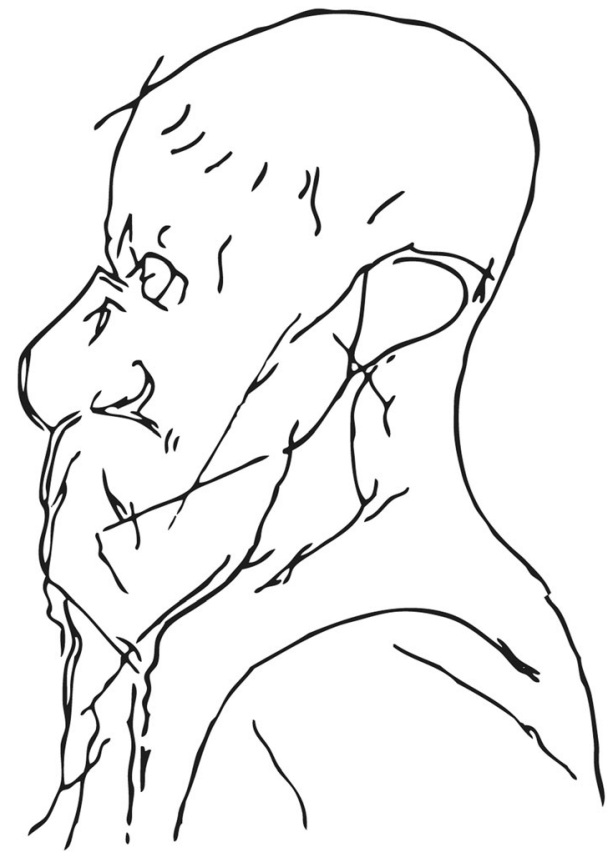

Fig. 5 An individualized human engraved, from the Cave of La Marche (Pales and Tassin de Saint-Péreuse 1976; Relevé L. Pales)

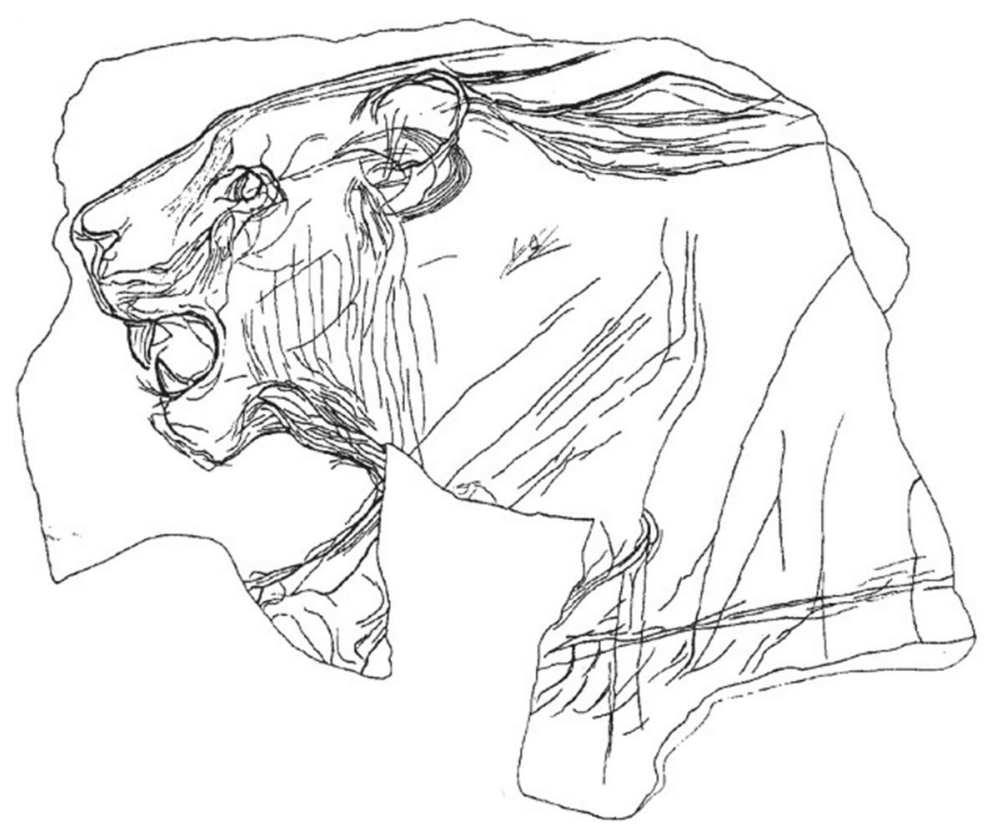

$2 \mathrm{~cm}$

Fig. 6 An individualized lion engraved, from the Cave of La Marche (Pales and Tassin de Saint-Péreuse 1989; Relevé L. Pales) 
number and nature of the associated secondary internal details vary greatly (Fig. 7). Depictions of the ear, forelock, nature of coat on the forepart of the horse's head, details of the lacrimal caruncle, relief of the mandible, open mouth, etc. all vary. Another graphic component which contributes to making each piece unique lies in the diverse technical methods used to depict the internal details: the eye (a straight, punctiform, circular, or double convex incision); the nostrils

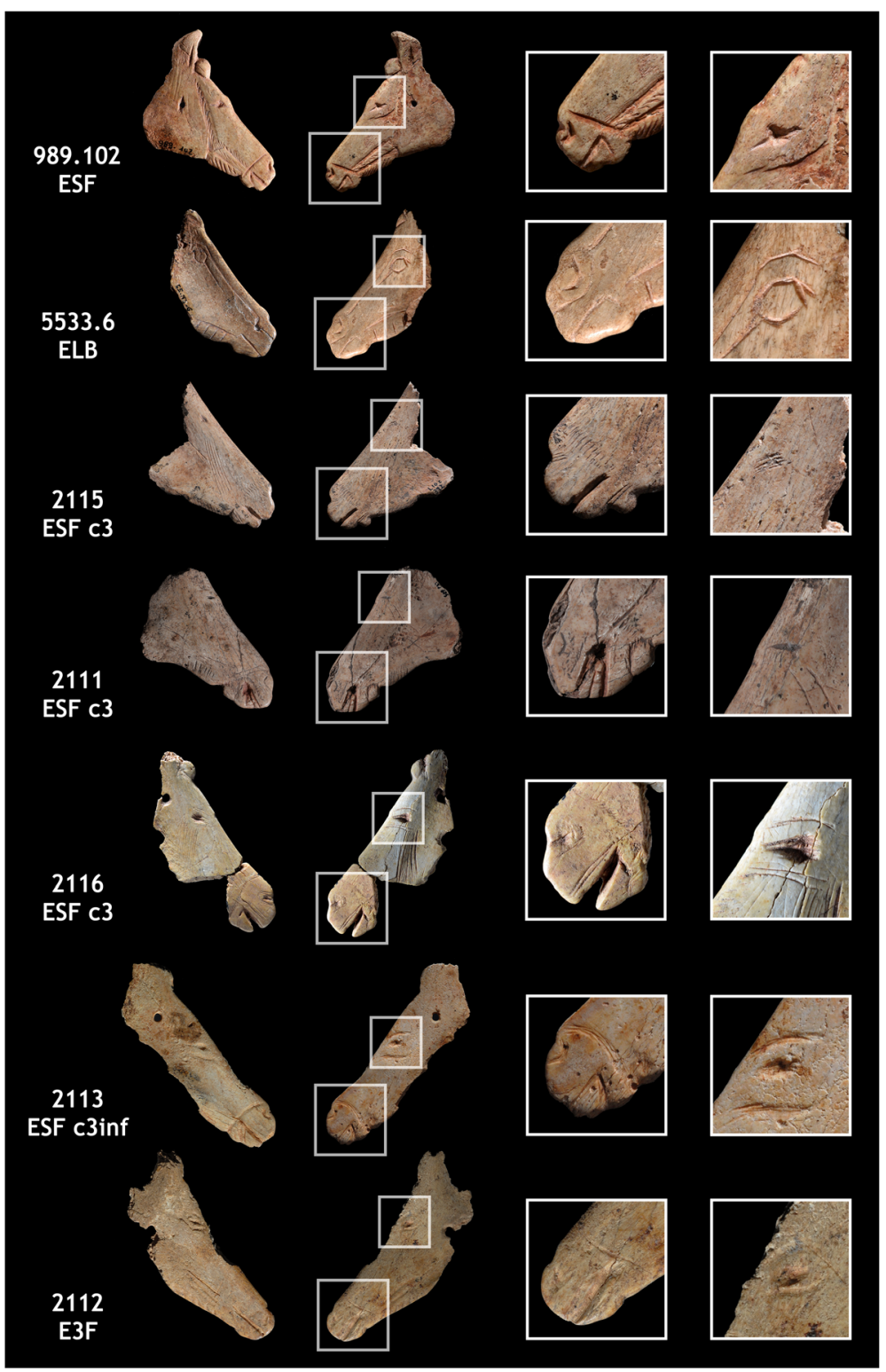

Fig. 7 "Contours découpés" in the shape of a horse's head and made on horse stylohyoid bones, from the Cave of Enlène. The two faces are very similar, while many details vary from one piece to another. Based on photographs (C) Association Louis Bégouën 
(ranging from a simple comma mark to the creation of relief using a champlevé technique); the outline of the muzzle (a single or double, straight or curved incision, or a line of horizontal hatching); and the orbit (a single, double or triple line in the form of an open band, or a single or double oval of hatched lines). The wide diversity of characteristics, which differ from one piece to the next, does not support the hypothesis of a simple involuntary variability resulting from the artisanal reproduction of the same motif. This is all the more so since each piece almost systematically presents two faces with similar treatment (Delporte 1990; Cattelain and Bellier 2014), confirming the artists' ability to standardize their productions when they wished. In addition, the exceptional case of engravings depicting contours découpés already mentioned (collective 1996: MAN 47076; Cattelain and Bellier 2014) (Fig. 3) involves two images which are very similar in their general design but which present some minor differences, as is generally observed between each contour découpé: "the left head has a pupil, but no toupee; the right head has a toupee and the beard is depicted" (collective 1996, p. 280).

It is possible that the pieces in each collection came from a diverse range of sources, which would explain their lack of homogeneity. Whatever the cause of this heterogeneity - the artists' desire to differentiate the objects produced, or a desire to collect objects of diverse origin - it seems to have involved a deliberate intention. Ultimately, each contour découpé belongs to a type but is not a stereotype, just as each animal it represents belongs to a species but can be distinguished as an individual, underlining their own uniqueness.

\section{The Treatment of Human Corpses}

Burials attributable to the Middle Magdalenian are relatively rare, and only six burials have thus far been identified with certainty (Henry-Gambier 2014; Henry-Gambier in Barshay-Szmidt et al. 2016). Burial is far from being the most frequent method involved in the treatment of deceased human bodies, since more than $90 \%$ of individuals have been identified from fragmentary remains and isolated skeletal elements from nonburial contexts (Le Mort and Gambier 1992). Human bones are generally found on occupied sites in the same areas as the bones of consumed animals and are considered waste. It is difficult to determine whether there was a selection of individuals for these remains, as they concern children, from birth to adolescence, and adults of both sexes (Orschiedt 2013). Furthermore, some of these remains demonstrate intentional manipulation, in most cases cut marks. The most frequent cut marks are those indicating the removal of flesh, and the large majority of these marks are found on the skull and mandibles (Orschiedt 2013). An abundance of cranial remains is observed at a large number of sites, and the hypothesis of the deliberate selection of this skeletal element seems likely (Gambier 1996; Orschiedt 2013).

These scattered bones therefore demonstrate both an overrepresentation of the skull and a more meticulous and intense treatment of this skeletal element. Given that the gestures observed show a greater insistence on the defleshing of the face, the intention could have been the treatment of the individual identity of the deceased, whatever the specific purpose involved - the destruction of the subjectivity of an enemy or paying 
respect to the deceased, for example. For, in general, the face is emblematic of individual identity and subjectivity (Ingold 2000, p. 124). ${ }^{12}$

\section{Butchery Procedures and Transporting Animal Carcasses}

The extensive disarticulation of the skeletons of hunted animals in the Middle Magdalenian has been likened to very similar procedures in some ethnographic contexts of hunters in the circumpolar north (Costamagno and David 2009; Kuntz et al. 2016). In these contexts, these ritualized butchery practices are intended to maintain a social relationship with the slaughtered animals, which are considered to be individuals of equivalent status to humans: "other-than-human persons" (Hallowell 1960).

An overrepresentation of ungulate skulls has also been observed at Middle Magdalenian sites (Kuntz et al. 2016). This overrepresentation cannot be attributed to differences in conservation, nor does it correspond to a logic of economic optimization, which would imply that only the most useful parts of the carcasses were brought back to the residential camps. We can therefore consider that Magdalenian populations placed particular value on this type of skeletal element (Kuntz et al. 2016), raising similar issues as the overrepresentation of human skulls.

\section{Taking the Analysis Further: Animal Faces}

Throughout these analyses, we can note the singular importance of the heads of animal and human individuals in the remains attributed to the Middle Magdalenian. The scattered human bones found at Middle Magdalenian sites mainly concern skulls, and it is these skeletal elements that show the most man-made modifications (Gambier 1996; Orschiedt 2013). Similarly, ungulate skulls are also overrepresented at Middle Magdalenian sites, and this cannot be explained by purely technical or nutritional reasons (Kuntz et al. 2016). Among the portable art, we can note the abundance of stone figures at Bédeilhac (Sauvet 2004) as well as the importance of isolated heads of horses (Sauvet and Rivero 2016; Delporte 1990).

Among the body ornamentation, the contours découpés are again emblematic pieces, since these objects most often involve horses' heads with faces that are each a little different from the next, making it possible to distinguish individuals. Moreover, the reference to the head in this case is both iconic and indexical (Peirce 1960, first ed. 1903), as the horses' heads are generally depicted on horse stylohyoid bones (Cattelain and Bellier 2014), which have themselves been obtained from a horse's skull. Finally, among the Middle Magdalenian rock art, the head is a frequently represented isolated element of an animal's body, in particular with regard to horses (Ruiz-Redondo 2016), and is the element which is depicted in the most detail at an iconographic level when the animal is represented in its entirety. The sensory organs are regularly depicted, notably the eye (Bégouën et al. 2009), as well as details of the coat in the area of the head (whiskers, fetlock, mane, etc.) which are rarely shown on the rest of the body

\footnotetext{
12 "As a surface, the face has some very unique properties. I can feel my own face, and others can see it. But it remains invisible to me. Where others see my face, I see the world. Thus, the face is the visible representation, in other peoples' eyes, of my own subjective presence as an agent of perception" (Ingold 2000, p. 124).
} 
(Bégouën et al. 2009). As a result, some depictions of animal heads in Middle Magdalenian rock art make it possible to distinguish individuals and even resemble real portraits, presenting the unique features of a face and its facial expression (Fig. 8).

This focus on the head, which can be observed both in the representations and in the bone remains, could potentially signal an interest in the individual identity and subjectivity of some humans and animals. It could thus confirm a tendency to individualize beings in certain contexts of the Middle Magdalenian.

\section{Discussion: The Relationship Between Human and Animal Individuals}

Beyond symbolic classification based on animal species, the individual scale seems to play a specific role among Middle Magdalenian remains. Moreover, some humans and animals taken as individuals seem to have been connected to each other through various means. The notion of "agency" in the sense given by Gell (1998) allows us to discuss a real interaction here between humans and animals in contexts involving images, since these figurative animals could be conceived as agents of social life in their own right.

In the decorated caves, the visitor's body is subject to a very specific context, which sometimes puts it in a singular relationship with an animal figure. Thus, it is at times necessary to slip alone through a narrow crevice to come face to face with an isolated figure (examples of this can be found at Niaux, Las Monedas, Le Tuc d'Audoubert, Rouffignac, Bédeilhac, Font-de-Gaume, etc.). This leads to an encounter foreseen between two individuals: an individual animal figure and a single

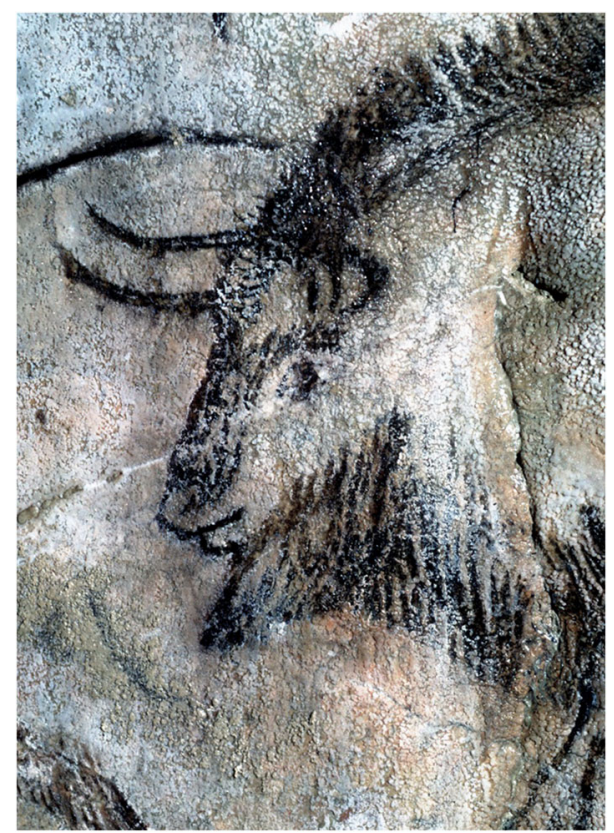

Fig. 8 A bison in the Cave of Niaux. (CThe Wendell collection, Neanderthal Museum 
possible observer. ${ }^{13}$ This intention can also be envisaged when anamorphic techniques are involved, assuming a preestablished view point for the observer-the only one from which the observer can correctly perceive the figure: for example, in the Salon Noir in Niaux, a natural hole above which a simplified antler is painted (Breuil 1952, p. 194) turns into the head of a deer seen from the front when the observer stands at the correct angle.

The small size of the engraved and/or sculpted objects on which unique animals have been depicted suggests that they were generally handled by humans in a personal relationship. Indeed, many individual actions have been documented on these objects, including destructive gestures, notably on the engraved stones, which have frequently been burned, fractured, and covered in invasive marks. The pieces have been found scattered or reused for other destructive purposes in a complex cycle of events around the act of engraving (Tosello 2003). Thus, these individual actions on engraved and sculpted stones representing animal individualities may reflect a practical connection between human and animal individuals.

In addition, in the case of the engraved stones, the large size of the assemblages, the heterogeneity in the degree of detail, and the probable on-site production of the engravings with material that was directly available are also characteristics that give the impression of collective rituals in which everyone could mark their participation by creating a personal animal "effigy" (Sauvet 2004). This would thus have established an interindividual relationship between the humans and the unique animal figures that they produced.

In another sense, the contour découpé ornaments are also a means of personalizing the human body. These pendants are decorated with individual animals, which are themselves distinctive and unique. The contours découpés were handled, worn, and transported by various human individuals, allowing for the direct association of animal individuals and human individuals. It has already been observed that each contour découpé can be distinguished among a collection of contours découpés, just as each horse can be distinguished within its species. This observation could be completed with parallel concerning human groups: each human who wears a contour découpé can be distinguished within their social group. Thus, an interweaving of different levels of relationships between human and animal individuals can be perceived in the contours découpés.

The same is true with regard to spear throwers with carved ornamentation (type 4 proposed by Cattelain 1988), which are sometimes considered "ornament tools" (Taborin 2004): the objects bear depictions of distinct animal individuals, making it possible to give each human user a unique identity too. Moreover, these tools were used for the purpose of hunting individual animals, thus creating a relationship between an individual human and an individual animal.

The desire to show respect for the animals, so as to ensure their complicity, is particularly common in societies in which hunting plays an important role (Tanner 1979; Hamayon 1990; Ingold 2000; Descola 2005; Cebolla 2013). Respecting certain rules and sometimes certain procedures during butchery generally gives the hunter hope

\footnotetext{
${ }^{13}$ It should nonetheless be noted that this kind of setting is not standard and that there are also, in contrast, settings which appear to have been collective (such as the sculpted friezes, for example) (Bourdier 2013; Bourdier et al. 2017).
} 
that an animal will offer itself voluntarily to them during a future hunting episode. It is a question of maintaining the cycle and good social relations with the animals hunted, which are considered close relatives (Ingold 2000). The exhaustive disarticulation of animal skeletons documented among the Evenk (Abe 2005) is precisely a way of demonstrating a respectful attitude toward the animal being handled. The same butchery practices that are observed for the Middle Magdalenian-for which there are no obvious technical, nutritional, or economic explanations - could reflect a similar intention (Costamagno and David 2009; Kuntz et al. 2016). If this were indeed the case, it would imply an interindividual relationship in its strongest sense between the hunter (and/or "butcher") and their prey.

\section{Conclusion}

In this article, I have proposed a reevaluation of some Middle Magdalenian remains in order to expand our knowledge of the relationships between humans and animals in this context. I have attempted to conduct a combined study of animal bones and animal depictions in order to test out the hypothesis of the individualization of certain humans and animals. This tendency to individualize humans and animals seems to be present in many fields: rock art, stone sculptures and engravings, body ornamentation, treatment of animal carcasses, and treatment of human corpses. In most of these areas, we can also observe the existence of practical techniques employed to create a relationship between human and animal individuals.

This tendency toward individualization does not exclude the possibility of other types of categorization, which could be combined with it. The concomitant existence of remains which only appear to reflect the species and remains for which an individualization of the subject is conceivable is by no means contradictory but rather brings further evidence of the complexity of the productions and behaviour of Magdalenian communities. As such, it is a further reason why we should study archaeological remains at different scales, testing different theoretical paradigms and crossing different disciplines.

Thus, while the notion of animal species is a means of classification that was of undeniable importance for the populations of the Upper Palaeolithic in Europe, as well as for the archaeologists studying them, this notion cannot summarize all the relationships that existed between humans and animals. For the Magdalenian, and perhaps for other Palaeolithic contexts too, beyond the very general human tendency to symbolize relationships through animal species, the manner of perceiving other beings sometimes appears to have spontaneously taken the form of individualization.

Acknowledgements I must first thank my fellow participants at the XVIII ${ }^{\circ}$ UISPP World Congress in Paris in June 2018, session XXVIII-3, Beyond images: New understandings of prehistoric art, where aspects of this article were presented. I thank the guest editors of this Special Issue "Art in the making" of the Journal of Archaeological Method and Theory, Oscar Moro Abadía and Manuel R. González Morales. I am grateful to the TRACES laboratory (CNRS - Université de Toulouse Jean Jaurès) for funding an English translation of this article. Thanks to Sarita Mardon for this English translation. 


\section{Compliance with Ethical Standards}

Conflict of Interest The author declares that he has no conflict of interest.

\section{References}

Abe, Y. (2005). Hunting and butchery patterns of the Evenki in northern Transbaikalia, Russia. Ph.D. dissertation, State University of New York at Stony Brook.

Airvaux, J. (2001). L'art préhistorique du Poitou-Charentes, sculptures et gravures des temps glaciaires. Paris : la Maison des roches.

Altuna, J. (1997). L'art des cavernes en Pays Basque. Ekain et Altxerri. Paris: Editions du Seuil.

Arias P., Ontanon R., Alvarez-Fernandez E., Cueto M., Elorza M., Garcia-Monco C., Güth A., Iriarte M.-J., Teira L.C., Zurro D. (2011). Magdalenian floors in the Lower Gallery of La Garma. A preliminary report. In Gaudzinski-Windheuser S., Joris O., Sensburg M., Street M., Turner E (Ed.), Site-internal spatial organization of hunter-gatherer societies: case studies from the European Palaeolithic and Mesolithic (pp. 31-51). Mainz : Romisch-Germanisches Zentralmuseum.

Aurière L. (2012). Réflexions autour des choix technologiques dans l'art mobilier paléolithique en matières osseuses : premières données des sites magdaléniens de Plantade, Lafaye, Courbet et Montastruc (vallée de l'Aveyron). In Clottes J. (Ed.), L'art pléistocène dans le monde. Actes du Congrès IFRAO (CD : pp.1493-1500). Tarascon-sur-Ariège : Préhistoire, Art et Sociétés, Bulletin de la Société Préhistorique Ariège-Pyrénées, 2010-2011.

Averbouh A., Feruglio V. (2012). L'art mobilier pléistocène: un symposium autour des orientations et des recherches actuelles. In Clottes J. (Ed.), L'art pléistocène dans le monde, Actes du Congrès IFRAO (CD: p.1267-1273). Tarascon-sur-Ariège : Art et Sociétés, Bulletin de la Société Préhistorique AriègePyrénées, 2010-2011.

Balbín, B. R., \& Moure Romanillo, J. A. (1981). Pinturas y grabados de la cueva de Tito Bustillo (Asturias): conjuntos II al VII. Boletin del Seminario de Estudios de Arte y Arqueología, 47, 5-43.

Balbín, B. R., \& Moure Romanillo, J. A. (1982). El panel principal de la cueva de Tito Bustillo (Ribadesella, Asturias). Ars Praehistorica, 1, 47-97.

Barrière, C. (1982). L'art pariétal de Rouffignac. La grotte aux cent mammouths. Paris: Picard.

Barshay-Szmidt, C., Costamagno, S., Henry-Gambier, D., Laroulandie, V., Pétillon, J.-M., Boudadimaligne, M., Kuntz, D., Langlais, M., \& Mallye, J.-B. (2016). New extensive focused AMS 14C dating of the Middle and Upper Magdalenian of the western Aquitaine/Pyrenean region of France (ca. 19-14 ka cal BP) : proposing a new model for its chronological phases and for the timing of occupation. Quaternary International, 414, 62-91.

Bégouën R., Clottes J. (1981). Apports mobiliers dans les cavernes du Volp (Enlène, Les Trois-Frères, Le Tuc d'Audoubert). Altamira Symposium. Madrid-Asturias-Santander, 15-21 octobre 1979 (pp.157-188). Madrid, Asturias, Santander, Ministerio de Cultura.

Bégouën R., Clottes J. (1990). Art mobilier et art pariétal dans les cavernes du Volp. In Clottes J. (Ed.), L'art des objets au Paléolithique, t.1 : L'art mobilier et son contexte, Colloque de Foix-Le Mas d'Azil, 1987, actes des colloques de la Direction du Patrimoine (pp.157-172).

Bégouën, R., \& Clottes, J. (2007). Compléments aux plaquettes gravées d'Enlène. Cuadernos de Arte Rupestre, 4, 51-80.

Bégouën, R., Fritz, C., Tosello, G., Clottes, J., Pastoors, A., Faist, F., in collaboration with Bourges, F, Fosse, P., Langlais, M., \& Lacombe, S. (2009). Le sanctuaire secret des bisons : il y a 14000 ans dans la caverne du Tuc d'Audoubert. In Montesquieu-Avantès: Association Louis Bégouën. Paris: Somogy.

Bégouën, R., Clottes, J., Feruglio, V., \& Pastoors, A. (2014). La caverne des Trois-Frères. Anthologie d'un exceptionnel sanctuaire préhistorique. Montesquieu-Avantès: Association Louis Bégouën; Paris: Somogy.

Beltrán, A., Robert, R., \& Vézian, J. (1966). La cueva de Le Portel. Zaragoza: Anejo de Caesaraugusta.

Birouste, C. (2018). Le Magdalénien après la nature, une étude des relations entre humains et animaux durant le Magdalénien moyen. Ph.D. dissertation, University of Toulouse Jean Jaurès.

Birouste C., Chauvière F.-X., Plassard F., \& Dachary, M. (2016). The horse mandibles at Duruthy rockshelter (Sorde-1'Abbaye, Landes, France) and the identification of ontological systems in the Pyrenean Magdalenian. Quaternary International, 414, 159-173. 
Birouste, C., Chauvière, F.-X., Plassard, F., \& Dachary, M. (2018). Les mandibules de cheval de l'abri Duruthy (Sorde-l'Abbaye, Landes): contexte archéologique et mise en perspective ontologique au sein du Magdalénien des Pyrénées . In Costamagno S., Dupond C., Dutour O., Gourichon L., Vialou D., (Ed.), Animal symbolisé - Animal exploité. Du Paléolithique à la Protohistoire. Paris : Édition du CTHS.

Bourdier C. (2010). Paléogéographie symbolique au Magdalénien moyen. Apport de l'étude des productions graphiques pariétales des abris occupés et sculptés de l'Ouest français (Roc-aux-Sorciers, Chaire-àCalvin, Reverdit, Cap-Blanc), Ph.D. dissertation, University of Bordeaux 1.

Bourdier, C. (2013). Rock art and social geography in the Upper Palaeolithic. Contribution to the sociocultural function of the Roc-aux-Sorciers Rock-Shelter (Angles-sur-l'Anglin, France) from the viewpoint of its sculpted frieze, Journal of Anthropological Archaeology, 32(4), 368-382.

Bourdier C., Birouste C. (2019). Les contours découpés de la grotte d'Enlène, in Begouën R., Pastoors A., Clottes J. (Ed.), La grotte d'Enlène, Immersion dans un habitat magdalénien. Association Louis BEGOUEN: Paris; In Fine: Paris.

Bourdier C., Bosselin B., Gaussein P., Paillet P., Pinçon G. (2016). Regards croisés sur la représentation animalière des faciès du Magdalénien à pointes de Lussac-Angles et à navettes : choix thématiques et formels, in Bourdier C., Chehmana L., Malgarini R., Połtowicz-Bobak M (Ed.), L'essor du Magdalénien. Aspects culturels, symboliques et techniques des faciès à Navettes et à Lussac-Angles,103-117. Actes de la séance de la Société préhistorique française de Besançon, 17-19 octobre 2013. Paris :Société préhistorique française.

Bourdier, C., Fuentes, O., \& Pinçon G. (2017). Methodological contribution to the integrated study of European Palaeolithic rock art: the issue of the audience and the perceptibility of Roc-aux-Sorciers rock art (Angles-sur-l'Anglin, France), Quaternary International, 430, 114-129.

Breuil H. (1952). Quatre cents siècles d'art pariétal. Les cavernes ornées de l'Age du Renne. Montignac : Centre d'Etudes et de Documentation Préhistoriques.

Buisson, D., Fritz, C., Kandel, D., Pinçon, G, Tosello, G., \& Sauvet, G. (1996). Analyse formelle des contours découpés de têtes de chevaux implications archéologiques. In Actes du 118e Congrès National des Sociétés Historiques et Scientifiques, Pau 25-29 octobre 1993 (pp.327-340). Paris : Edition du CTHS.

Castel, J.-C., Kuntz, D., Chauvière, F.-X., Gerbe, M., \& Juillard, F. (2007). Archéozoologie du Paléolithique supérieur en Quercy. in Jarry M. (Ed.), Cultures et environnements paléolithiques : mobilité et gestion des territoires des chasseurs-cueilleurs en Quercy (pp.295-306). Rapport final d'ACR.

Cattelain, P. (1988). Fiches typologiques de l'industrie de l'os préhistorique. Cahier II : Propulseurs. Aix-enProvence : Université de Provence.

Cattelain P., Bellier C. (2014). Objets décorés pris sur stylohyoïde, in Fiches typologiques de l'Industrie de l'os préhistorique. Cahier XII : Matière d'art. p.91-104. Arles : Actes-Sud.

Cebolla, B. M. (2013). Cosmología y naturaleza mbya-guaraní. Ph.D. dissertation, University of Barcelona..

Clottes, J. (2010). Les Cavernes de Niaux: Art préhistorique en Ariège - Pyrénées. Paris: Editions Errance.

Clottes, J., Garner, M., \& Maury, G. (1994). Bisons magdaléniens des cavernes ariègeoises, Bulletin de la société préhistorique Ariège-Pyrénées, 49, 15-49.

Collective (1996). L'art préhistorique des Pyrénées, Catalogue d'exposition, Musée des Antiquités Nationales de Saint-Germain-en-Laye, Réunion des musées nationaux, 2 avril-8 juillet 1996, Paris.

Costamagno S. (1999). Stratégies de chasse et fonction des sites au Magdalénien dans le sud de la France, Ph.D. dissertation, University of Bordeaux 1.

Costamagno, S., \& David, F. (2009). Comparaison des pratiques bouchères et culinaires de différents groupes sibériens vivant de la renniculture. Archaeofauna, 19, 9-25.

Costamagno, S., \& Mateos, C. A. (2007). Milieu animal de part et d'autre de la chaîne pyrénéenne : implications sur les modes de subsistance au Magdalénien. In N. Cazals, J. González Urquijo, \& X. Terradas (Eds.), Frontières naturelles et frontières culturelles dans les Pyrénées préhistoriques, Actes du colloque de Tarascon-sur-Ariège, mars 2004 (pp. 51-73). Barcelona: Museo de Cataluña.

Costamagno, S., Laroulandie, V., Langlais, M., \& Cochard, D. (2009). Exploitation du monde animal sur le versant nord des Pyrénées au Tardiglaciaire. In J.-M. Fullola, N. Valdeyron, \& M. Langlais (Eds.), Els Pirineus i les arees circumdants durant el Tardiglacial. Mutacions i filiacions tecnoculturals evolucion paleoambiental, Actes du 16ème colloque international d'archéologie de Puigcerda, Hommage à G. Laplace (pp. 185-209). Institut d'Estudis Ceretan: Puigcerda.

Costamagno, S., Barshay-Szmidt, C., Kuntz, D., Laroulandie, V., Pétillon, J. M., Boudadi-maligne, M., Langlais, M., Mallye, J. B., \& Chevallier, A. (2016). Reexamining the timing of reindeer disappearance in southwestern France in the larger context of late glacial faunal turnover. Quaternary International, 414, 34-61.

Coye N. (1997). La préhistoire en paroles et en actes. Méthodes et enjeux de la pratique archéologique (1830-1950). Paris : L’Harmattan, Collection Histoire des Sciences Humaines. 
Cuvier, G., (1985, first ed. 1825). Discours sur les révolutions de la surface du globe et sur les changements qu'elles ont produits dans le règne animal. Paris : C. Bourgeois.

Delpech F. (1989). L'environnement animal des magdalénien, in : M. Otte (Ed.) Le Magdalénien en Europe. La structuration du Magdalénien, pp.5-30. Liège : ERAUL.

Delporte, H. (1990). L'image des animaux dans l'art préhistorique. Paris : Picard.

Descola, P. (2005). Par-delà nature et culture. Paris : Gallimard, Bibliothèque des sciences humaines.

Fontana, L. (1999). Mobilité et subsistance au Magdalénien dans le bassin de l'Aude. Bulletin de la Société préhistorique française, 96(2), 175-190.

Freeman, L. G., \& Gonzalez, E. J. (2001). La Grotte d'Altamira. Paris : La maison des Roches.

Fritz C. (2010). Le Magdalénien, in : Clottes J. (Ed.), La France préhistorique. Essai d'histoire. Paris : Gallimard.

Fritz C., Simonnet R. (1996). Du geste à l'objet : les contours découpés de Labastide, résultats préliminaires, TECHNE, la science au service de l'art et des civilisations. pp.63-77. Paris : Edition du Laboratoire de Recherche des Musées de France, Réunion des Musées Nationaux.

Fuentes, O. (2015). Image de soi en préhistoire. Essais sur les enjeux de la représentation humaine pour les sociétés magdaléniennes, in Brancier J., Remeaud C., Vallette T. (Ed.), Des vestiges aux sociétés : Regards croisés sur le passage des données archéologiques à la société sous-jacente. Paris: Publications de la Sorbonne, < http://books.openedition.org/psorbonne/4546 >.

Fuentes, O., \& Pinçon, G. (2018). Essai d'une anthropologie des images paléolithiques du Roc-aux-Sorciers (Angles-sur-l'Anglin, Vienne, France) : entre continuités et discontinuités, PALEO, 29, 137-149.

Fuentes O., Lenoir M., Martinez M., Welté A-C (2016). Les représentations humaines et leurs enjeux. Regards croisés entre le Roc-aux-Sorciers (Angles-sur-l'Anglin, Vienne) et le Roc-de-Marcamps (Prignac-deMarcamps, Gironde), in Bourdier C., Chehmana L., Malgarini R., Połtowicz-Bobak M (Ed.), L'essor du Magdalénien. Aspects culturels, symboliques et techniques des faciès à Navettes et à Lussac-Angles,119135. Actes de la séance de la Société préhistorique française de Besançon, 17-19 octobre 2013. Paris :Société préhistorique française.

Gambier D. (1996). Les pratiques funéraires au Magdalénien dans les Pyrénées françaises. In H. Delporte et J. Clottes (Ed.), Pyrénées préhistoriques, arts et sociétés, actes du 118 e Congrès des sociétés historiques et scientifiques (Pau, 25-29 octobre 1993), 263-277. Paris : Edition du CTHS.

Gell, A. (1998). Art and agency, an anthropological theory. Oxford: Clarendon Press.

González Sainz, C., \& Utrilla, P. (2005). Problemas actuales en la organización y datación del Magdaleniense de la Región Cantábrica. Actas do IV Congresso de Arqueología Peninsular. O Paleolítico. Faro, 14 a 19 de septiembre de 2004, 39-4.

Groenen M. (1994). Pour une histoire de la préhistoire: Le Paléolithique. Grenoble : Jérôme Millon, coll. « L'Homme des Origines »).

Guthrie R. D. (1984). Ethological Observations from Palaeolithic Art, In Bandi H.G., Huber W., Sauter M-R., Sitter B. (eds.), La Contribution de la Zoologie et de l'Ethologie à l'Interpretation de l'Art des Peuples Chasseurs Prehistoriques. Fribourg: Editions Universitaires Fribourg Suisse, 35-74.

Hallowell, A. I. (1960). Ojibwa ontology, behavior, and world view. Readings in indigenous religions, 22, 1749.

Hamayon, R. (1990). La Chasse à l'âme. Esquisse d'une théorie du chamanisme sibérien. Nanterre : société d'ethnologie (Université de Paris X).

Henry-Gambier D. (2014). Les pratiques funéraires magdaléniennes en Europe. In Grands sites d'art Magdaléniens. La Madeleine et Laugerie-basse il y a 15000 ans (pp.53-57). Paris : Réunion des musées nationaux, Grand Palais.

Iakovleva, L., \& Pinçon, G. (1997). Angles-sur-l'Anglin (Vienne). La frise sculptée du Roc-aux-Sorciers. Paris : RMN, CTHS.

Ingold, T. (2000). The perception of the environment: essays on livelihood, dwelling and skill. London: Routledge.

Kuntz, D., Costamagno, S., Feyfant, L., \& Martin, F. (2016). The exploitation of ungulates in the Magdalenian in the Entre-Deux-Mers (Gironde, France). Quaternary International, 414, 1-24.

Laming-Emperaire, A. (1962). La Signification de l'art rupestre paléolithique : Méthodes et applications. Paris: Picard.

Langlais, M. (2007). Dynamiques culturelles des sociétés magdaléniennes dans leurs cadres environnementaux: enquête sur 7000 ans d'évolution de leurs industries lithiques entre Rhône et Èbre. These de doctorat, Université Toulouse le Mirail; Universitat de Barcelona.

Langlais M., Costamagno S., Laroulandie V., Pétillon J.-M., Discamps E., Mallye J.-B., Cochard D., Kuntz D. (2012). The evolution of Magdalenian societies in South-West France between 18000 and 14000calBP : 
changing environments, changing tool kits. In Straus L.-G., Terberger T., Leesch D. (Ed.), The Magdalenian settlement of Europe, Quaternary International, 272-273, 138-149.

Laroulandie V. (2000). Taphonomie et archéozoologie des Oiseaux en grotte : applications aux sites Paléolithiques du Bois-Ragot (Vienne), de Combe Saunière (Dordogne) et de La Vache (Ariège). Ph.D. dissertation, University of Bordeaux 1.

Lartet, E. (1860). Note sur des os fossiles portant des empreintes ou entailles anciennes et attribuées à la main de l'homme. Bulletin de la Société Géologique de France, 2(17), 492-495.

Lartet, E., \& Christy, H. (1864). Sur des figures d'animaux gravées ou sculptées et autres produits d'art et d'industrie rapportables aux temps primordiaux de la période humaine. Revue archéologique, 9, 233-267.

Le Mort F., Gambier D. (1992). Diversité du traitement des os humains au Magdalénien : un exemple particulier, le cas du gisement du Placard (Charente). In Le peuplement magdalénien : paléogéographie physique et humaine. Actes du colloque de Chancelade, 10-15 octobre 1988 (pp.29-40). Paris : Comité des Travaux Historiques et Scientifiques.

Leroi-Gourhan, A. (1965). Préhistoire de l'art occidental. Paris: Mazenod.

Leroi-Gourhan, A. (1983). Le fil du temps. Paris: Fayard.

Lévi-Strauss, C. (1990, first ed. 1962). La pensée sauvage. Paris : Pocket, collection Agora.

Lorblanchet, M. (2010). Art pariétal : grottes ornées du Quercy. Rodez : Editions du Rouergue.

Mélard, N. (2008). Pierres gravées de la Marche à Lussac-les-Châteaux (Vienne) : techniques, technologie et interprétations. Gallia préhistoire, 50(1), 143-268.

Ontanon R., Arias P. (2012). Decorated plaquettes from Magdalenian habitation floors in the Lower Gallery at La Garma (Cantabria, Spain). In Clottes J. (Ed.), L'art pléistocène dans le monde, Actes du Congrès IFRAO (CD: p.1393-1410). Tarascon-sur-Ariège : Préhistoire, Art et Sociétés, Bulletin de la Société Préhistorique Ariège-Pyrénées 2010-2011.

Orschiedt J. (2013). Bodies, bits and pieces: burials from the Magdalenian and the Late Palaeolithic. In Pastoors A. et Auffermann B. (Ed.), Pleistocene foragers: their culture and environment. Festchrift in honour of Gerd-Christian Weniger for his sixtieth birthday. Wissenschaftliche Schriften des Neanderthal Museums, 6.

Paillet, P. (2014). L'art des objets de la Préhistoire : Laugerie-Basse et la collection du marquis Paul de Vibraye au Muséum national d'histoire naturelle. Arles : Errance.

Pales, L., \& Tassin de Saint-Péreuse, M. (1976). Les gravures de La Marche, II, Les Humains. Paris : Ophrys.

Pales, L., \& Tassin de Saint-Péreuse, M. (1981). Les gravures de La Marche, III, Equidés et bovidés. Paris: Ophrys.

Pales, L., \& Tassin de Saint-Péreuse, M. (1989). Les gravures de La Marche, IV, Cervidés, mammouths et divers. Ophrys: Gap.

Peirce, C. S. (1960, first ed. 1903). Elements of logic. In Collected Papers of Charles Sanders Peirce. Cambridge : Harvard University Press.

Peyroux, M. (2012). Les dépôts d'objets pariétaux des grottes ornées au Paléolithique supérieur : gestes, comportements symboliques, cultures. Ph.D. dissertation, University of Bordeaux 1.

Plassard, F. (2005). Les grottes ornées de Combarelles, Font-de-Gaume, Bernifal et Rouffignac : contexte archéologique, thèmes et style des représentations. Ph.D. dissertation, University of Bordeaux 1.

Plassard, J. (1999). Rouffignac, le sanctuaire des mammouths. Paris: Seuil.

Richard, N. (1992). L'invention de la préhistoire, une anthologie. Paris: Presses Pocket.

Ripoll, P. E. (1972). La cueva de las Monedas en Puente Viesgo (Santander). Barcelona: Diputación Provincial, Instituto de Prehistoria y Arqueología.

Rivero, O., \& Sauvet, G. (2014). Defining Magdalenian cultural groups in Franco-Cantabria by the formal analysis of portable artworks. Antiquity, 88(339), 64-80.

Ruiz-Redondo, A. (2016). Le comportement symbolique des derniers chasseurs cueilleurs paléolithiques: regard sur l'art rupestre du Magdalénien cantabrique. L'Anthropologie, 120(5), 568-587.

Saint-Mathurin (de) S. (1973). Bas-relief et plaquette de l'homme magdalénien d'Angles-sur-l'Anglin. Antiquités Nationales, 5, 12-19.

Sauvet, G. (2004). L'art mobilier non classique de la grotte magdalénienne de Bédeilhac (Ariège). In M. Lejeune et A.-C. Welté (dir.), L'Art du Paléolithique supérieur, Actes du XIVe congrès de l'UISPP, Liège, Septembre 2001 (pp.167-176). Liège : ERAUL.

Sauvet G., Rivero O. (2016). D'un support à l'autre: l'art pariétal à la lumière de l'art mobilier. PALEO, numéro spécial, 133-147.

Sauvet, G., Wlodarczyk, A. (1995). Eléments d'une grammaire formelle de l'art pariétal paléolithique, L'Anthropologie, 99, n²/3, 193-211.

Sauvet G., Layton R. H., Lenssen-Erz T., López-Montalvo E., Taçon P., Wlodarczyk A. (2012). De l'iconographie d'un art rupestre à son interprétation anthropologique, in Clottes J. (Ed.), L'art 
pléistocène dans le monde, Actes du Congrès IFRAO, Tarascon-sur-Ariège, septembre $2010, \mathrm{~N}^{\circ}$ spécial de Préhistoire, Art et Sociétés, LXV-LXVI, 2010-2011, cd :1763-1776.

Sieveking, A. (1987). Engraved Magdalenian Plaquettes. A regional analysis of stone, bone and antler plaquettes from Upper Palaeolithic sites in France and Cantabric Spain, British Archaeological Reports International Series, 369, 1.

Soulier M.-C., Kuntz D., Lacarrière J., Castel J.-C. (2014). Le Renne comme ressource alimentaire : discussion entre pratiques actuelles et paléolithiques. In S. Costamagno (Ed.) Histoire de l'alimentation humaine : entre choix et contraintes, Actes du 138 e Congrès national des sociétés historiques scientifiques tenue à Rennes en 2013 (pp.153-169). Paris: Éditions du CTHS.

Taborin, Y. (2004). Langage sans parole : la parure aux temps préhistoriques. Paris : la Maison des roches.

Tanner A. (1979). Bringing home animals. Religious ideology and mode of production of the Mistassini Cree hunters. London: C. Hurst.

Tosello, G. (2003). Pierres gravées du Périgord magdalénien. Art, symboles, territoire. Paris: CNRS.

Vialou, D. (1986). L'art des grottes en Ariège magdalénienne. Paris: CNRS.

Walker, S. (2000). Ancient faces : mummy portraits from Roman Egypt. New York: Routledge.

White, R. (2003). L'art préhistorique dans le monde. Paris : Editions de la Martinière.

Publisher's Note Springer Nature remains neutral with regard to jurisdictional claims in published maps and institutional affiliations. 